\title{
Narrowing the Gaps: Assessment of Logistics Firms' Information Technology Flexibility for Sustainable Growth
}

\author{
Jeong Hugh Han ${ }^{1, *}$, Yingli Wang ${ }^{2}$ and Mohamed Naim ${ }^{2}$ \\ 1 Asia Pacific School of Logistics, Inha University, Incheon 22212, Korea \\ 2 Logistics and Operations Management Section, Cardiff Business School, Cardiff University, \\ Cardiff CF10 3EU, UK; wangy14@cardiff.ac.uk (Y.W.); naimmm@cardiff.ac.uk (M.N.) \\ * Correspondence: hanjh@inha.ac.kr
}

Received: 28 April 2020; Accepted: 21 May 2020; Published: 26 May 2020

\begin{abstract}
In a supply chain management context, the effective management of Information Technology (IT) flexibility has been an issue to be resolved. However, no analytical method that calculates the required and actual level of IT flexibility dimensions has been proposed. This paper aims to provide an analytical tool that measures the required and actual levels of IT flexibility dimensions to provide the best value from a logistics firm's IT flexibility. To do so, we propose a combined Importance-Performance Analysis (IPA) and Partial Least Squared Structured Equation Modelling (PLS-SEM) method based on a multidimensional IT flexibility model. By comparing industry-level data with client firm data, our method allows for effective identification of a client logistics company's multiple IT flexibility gaps and indicates where particular management interventions are required. By proposing importance and performance as measurement scales, our research suggests an analytical tool that managers can utilize to assess IT flexibility and identify any gaps that exist between actual and required flexibility levels. This allows managers to effectively address areas that demand further attention. This approach also leads to an improved understanding of how organisations can extract the best value from their investment in IT flexibility to contribute to sustainable growth.
\end{abstract}

Keywords: flexibility; IT flexibility; importance-performance analysis; partial least squared structured equation modelling; performance gap; sustainable growth

\section{Introduction}

Information Technology (IT) flexibility is one of the most widely used concepts for identifying a firm's ability to cope with the variation generated by its business environment [1-4]. With the recognition of IT flexibility as a multidimensional concept, previous research has focussed on the identification of, and validated the dependence of firm performance on, IT flexibility dimensions [5-9]. Further, as echoed by several researchers [4,10-13] an investigation of the mismatches between the actual and required level of each flexibility dimension is required to execute efficient resource allocation to each dimension so that finite firm resources can be used effectively. However, little attention has been given to a method to improve firm performance through a flexibility requirements analysis. Specifically, there has been a lack of analytical tools that calculate the required and actual level of IT flexibility dimensions, hence impeding strategic decision-making in resource investment.

To fill this research gap, we suggest the use of Importance-Performance Analysis (IPA), combined with Partial Least Squared Structured Equation Modelling (PLS-SEM), to identify the gaps between the required and actual levels of each flexibility dimension. We particularly highlight the usefulness of this application, which indicates particular dimensions that might be under- or over-resourced. 
The combined use of IPA and PLS-SEM is a largely neglected method, particularly in the Technology Management field. To the best of our knowledge, our paper is the first to apply combined IPA and PLS-SEM in the context of operational flexibility more generally, and IT flexibility specifically.

The rest of the paper is organised as follows. Section 2 offers a theoretical background for managing multiple flexibility dimensions. Section 3 discusses our methodological approach in applying IPA to examine the IT flexibility gap. This is followed by a discussion of our research findings in Section 4 . We draw conclusions in Section 5 by highlighting our theoretical and practical contributions. We also acknowledge our research limitations and discuss future research directions.

\section{Literature Review-Managing Multiple Dimensions of IT Flexibility}

There is general agreement that IT should be flexible to help companies deal with outward uncertainties through advancing, adapting or coordinating the functionalities of the IT. IT flexibility is thought to increase the capacity for adjust to variations in internal and external business circumstances. For instance, adaptability to novel or dissimilar circumstances and scalability [8], IT investment and IT infrastructure to adapt to a changing business environment [10], support to alter business strategies [14], information system functionality, database, interface and processing capacity [3], compatibility, information sharing, modularity and capacity to handle multiple applications [15], adaptability for changing business partners and environment, reconfiguration of communication linkages and capability to redesign business process are highlighted as the principal components of IT flexibility [1].

IT flexibility is a multidimensional concept. The seminal work of Duncan [2] categorised IT flexibility dimensions into compatibility, connectivity and modularity, focusing on IT infrastructure. On the other hand, Saraf et al. [6] claimed that the value of IT flexibility depends on the ability to adapt to the different types of business requirements that emerge from different organisational levels (e.g., operational tactical and strategical levels). So, to generate value, a continuous redesign of IT infrastructure that supports incremental and revolutionary environmental changes is required. By defining IT flexibility as the manner in which a firm's IT is organised and integrated to adapt to rapid changes, Saraf et al. [6] proposed scalability, system design for new business relationships, and system design for rapid business requirement change as the primary components of IT flexibility. Gosain et al. [16] give examples of different resource uses. According to Gosain et al. [16], if there is a need to change business partners quickly then IT should be exploited to lower the switching costs. If the capability requirement is to increase the volume of interfirm business transactions, IT should enable enhanced information sharing via the standardisation of processes.

Lee and Xia's [17] findings also strongly support the multidimensional characteristics of IT flexibility. They identified that two types of IT flexibility co-exist, namely response extensiveness and response efficiency. The multidimensionality of IT flexibility is also recognised in a comprehensive review by Kumar and Stylianou [4]. They pointed out that prior research focused on information technology infrastructure flexibility and highlighted the importance of IT flexibility as both a strategic and an organizational capability. Specifically, flexibility in IT operations, IT service development and IT management that responds to changing business process and consumer requirements are viewed as IT flexibility categories. Another contribution to defining the different roles of IT flexibility dimensions was supplied by Han et al. [11]. By integrating the traditional infrastructure-focused view and value creation in their IT flexibility dimensions, they revealed that IT flexibility encapsulates transactional, operational and strategic flexibilities, and further tested the causal effect between three dimensions and firm performance. From the perspective of a technology acceptance model, Kwak et al. [18] showed that information reliability, networking capability and security of a logistics platform are the logistics platform dimensions that increase the logistics platforms' dynamic capabilities. In particular, Kwak et al. [18] highlighted the role of scalability as a part of networking capability. They argue that the scalability of the logistics platform enables network effects so increases the flexibility of the logistics platform in responding to changing business demand. 
Despite previous research efforts in articulating the multiple dimensions of IT flexibility and their influence on firm performance, there have been limited discussions of how to interrogate the effectiveness of each flexibility dimension. Lee and Xia [17] and Kumar and Stylianou [4] are the notable exceptions that discuss the possible trade-offs among different dimensions of flexibility for firm performance. Kumar and Stylianou [4] argued that different IT flexibility dimensions play different roles and make synergies or conflicts in different situations requiring IT flexibility. Even though Kumar and Stylianou [4] did not provide the exact meaning of the trade-off, synergies and conflict, they implicitly argued that a set of concurrent actions that address specific needs for IT flexibility could be developed when the required and actual levels of flexibility are identified. Lee and Xia [17] argued that the gap between existing and desired IT flexibility should be identified by helping "managers attack the flexibility gap by developing theories" (p. 88). However, none of them was able to propose how such trade-offs or gap closing could be conducted.

Given the limited IT flexibility literature on assessing how well a firm performs against industry norms, we refer to the well-established OM flexibility literature that indicates the following practices are required to measure the flexibility gap. First, the desired configuration of heterogeneous dimensions of flexibility should be identified; that is, identifying the required level of flexibility needed within each dimension to yield performance benefits [19-22]. Second, an analysis of actual performance within each flexibility dimension is undertaken to identify performance mismatches between the required and observed levels of IT flexibility [20,23-26]. This process of performance measurement identifies where the flexibility levels may need to be raised or reduced [21]. Third, once a given performance gap has been identified, a management decision is required as to where to close the gaps at an acceptable cost $[21,23,26,27]$.

The aforementioned process may provide a good guideline to identify the gaps in IT flexibility. However, the flexibility measuring process still has a number of limitations. One of the core reasons is the absence of universal criteria that encompass different flexibility dimensions. Different flexibility dimensions are not homogenous and hence require different measures [28-30]. For instance, Cousens et al. [27] propose a series of steps for increasing manufacturing flexibility and suggested six key performance indicators (KPIs) to measure volume and mix flexibility in manufacturing. However, because the KPIs are very factory-specific, such as the number of variants per key product family, one cannot use them as a total set for the measurement for other dimensions such as labour or material handling flexibility. Seebacher and Winkler [31] also measured flexibility by developing a two-dimensional framework to identify the performance and usefulness of batch production systems. Their method of evaluating manufacturing flexibility is to compute a coefficient of variation from the deviations of the manufacturing order lead times and then calculate an efficiency in manufacturing performance. Although their approach is effective for evaluating manufacturing flexibility, they acknowledge that the application of the model is restricted to discrete manufacturing due to the specific parameters adopted (i.e., coefficient of variation).

Flexibility is a relative, situation-specific concept, so a certain dimension is viewed as a more imperative dimension when a specific environmental necessity emerges [32]. This relative importance in different situations also makes the flexibility measurement difficult. For instance, when a large variety of service accessibility and speedy transition proficiency exists, they both denote the flexibility concept. When the marketplace needs an advanced level of service diversity for a specific situation or time, the flexible capability for a large variety of services would take greater value [32,33]. The biased measurements used for flexibility performance are a similar problem. For example, existing empirical studies, such as Chang [34], have only prioritized the required flexibility dimensions in environmental uncertainty, and therefore are unable to identify actual levels of flexibility dimensions. As a result, they offer limited insights into identifying the flexibility gap to be closed.

Further, previous research has also suggested the need to show the link between an increased level of flexibility and the improvement of firm performance. To show that firm performance is conditional and dependent on flexibility levels, concurrent validation of the positive impact of 
flexibility configurations should also be undertaken [35-40]. However, much of the performance research in flexibility-related works has focused on the justification of IT flexibility dimensions and/or their impact on firm performance and has not extended to requirements analysis [38-40]. The most relevant work regarding the decision-making process and how to fill the performance gap is probably the work of He et al. [23]. By developing the concept of "flexibility fit," they showed that the levels of required and available flexibility can be determined through a set of simulations. However, as their guidelines were limited to a single dimension of process flexibility, i.e., range, it is not clear if their approach can be applied to the multiple flexibility dimensions found within a firm. Focusing on a single dimension overlooks the fact that multidimensionality is an essential attribute of a flexibility construct, and resources within a firm need to be shared in a cost-effective manner.

Therefore, given the limitations of existing flexibility research as Table 1 presents, namely the lack of objective measurements for different dimensions of flexibility and the lack of methods to determine the correlation between the level of IT flexibility and firm performance, the opportunity to close the flexibility gaps is lacking in previous literature. Furthermore, it would be difficult to pinpoint specific areas where a proper action plan can be devised for resource allocation or adjustment. The same problem exists for IT flexibility gap measurements. There is therefore a need for an effective tool that measures both the required and observed flexibility levels exploiting comprehensive, objective criteria. Those criteria also need to be aligned with different flexibility dimensions while showing uniformity towards performance improvement. 
Table 1. Key literature related to efficient IT flexibility management.

\begin{tabular}{|c|c|c|}
\hline Study & Research Objectives & Key Findings/Limitation \\
\hline $\begin{array}{l}\text { Bamel and Bamel, } \\
\quad 2018 \text { [35] }\end{array}$ & $\begin{array}{c}\text { To investigate the relationship of organizational resources } \\
\text { and strategic flexibility through knowledge management } \\
\text { process capability }\end{array}$ & $\begin{array}{l}\text { Organizational resources are associated positively with strategic flexibility, and } \\
\text { knowledge management process capability have mediating impact on these } \\
\text { relationships/Not extended to the flexibility gap closing process }\end{array}$ \\
\hline $\begin{array}{l}\text { Benitez et al. } 2018 \\
\text { [36] }\end{array}$ & $\begin{array}{l}\text { To investigate how information technology infrastructure } \\
\text { flexibility influence merger and acquisition (M\&A) of firms }\end{array}$ & $\begin{array}{c}\text { A flexible IT infrastructure facilitates business flexibility in capturing M\&A } \\
\text { opportunities and increasing post-M\&A IT integration capability/Not extended to } \\
\text { the flexibility gap closing process }\end{array}$ \\
\hline $\begin{array}{l}\text { Benitez et al. } 2018 \\
\text { [37] }\end{array}$ & $\begin{array}{l}\text { To capture the positive relationships between IT } \\
\text { infrastructure capability and business flexibility. }\end{array}$ & $\begin{array}{l}\text { IT-enabled business flexibility supports firms to develop the operational } \\
\text { proficiency to capture the new business opportunities and increase their } \\
\text { performance/Not extended to the flexibility gap closing process }\end{array}$ \\
\hline Boyle, 2006 [19] & $\begin{array}{c}\text { To develop a research framework that provides best } \\
\text { management practices in implementing manufacturing } \\
\text { flexibility. }\end{array}$ & $\begin{array}{l}\text { Measurement of required flexibility and processing of achieving required } \\
\text { flexibility process is proposed/No empirical research is presented }\end{array}$ \\
\hline $\begin{array}{l}\text { Cousens et al. } \\
\text { 2009 [27] }\end{array}$ & $\begin{array}{l}\text { To design a process that define the key activities of } \\
\text { a strategic manufacturing plan for the improved } \\
\text { manufacturing flexibility }\end{array}$ & $\begin{array}{l}\text { A change management process for flexibility performance improvement is } \\
\text { identified/Focusing on factory-specific flexibility so one cannot use them as a total } \\
\text { set for measurement for IT flexibility dimensions }\end{array}$ \\
\hline $\begin{array}{l}\text { Chaudhuri et al. } \\
\text { 2018 [41] }\end{array}$ & $\begin{array}{c}\text { To examine the impact of internal integration, external } \\
\text { integration and supply chain risk management on } \\
\text { manufacturing flexibility. }\end{array}$ & $\begin{array}{l}\text { Internal integration and supply chain risk management have a direct influence on } \\
\text { manufacturing flexibility/Not extended to the flexibility gap closing process }\end{array}$ \\
\hline Gao et al. 2020 [38] & $\begin{array}{l}\text { To investigate how IT business spanning capability } \\
\text { interacts with IT flexibility and IT integration, which } \\
\text { influence organizational agility. }\end{array}$ & $\begin{array}{l}\text { IT flexibility and IT integration are positively inter-related with organizational } \\
\text { agility/Not extended to the flexibility gap closing process }\end{array}$ \\
\hline He et al. 2012 [23] & $\begin{array}{l}\text { To guide process flexibility investment by establishing } \\
\text { a flexibility fit index }\end{array}$ & $\begin{array}{l}\text { 'Flexibility fit' is acquired by quantifying the required process flexibility/Flexibility } \\
\text { fit is limited to a single specific dimension of process flexibility (i.e., range) }\end{array}$ \\
\hline Hou, 2019 [39] & $\begin{array}{l}\text { To investigate the mediating role of supply chain } \\
\text { capabilities on the inter-relationships between IT } \\
\text { infrastructure flexibility, integration and firm performance. }\end{array}$ & $\begin{array}{l}\text { IT infrastructure integration and flexibility indirectly and positively influence } \\
\text { organizational performance with the mediating role of supply chain } \\
\text { capability/Not extended to the flexibility gap closing process }\end{array}$ \\
\hline $\begin{array}{l}\text { Irfan et al. } 2019 \\
\quad[40]\end{array}$ & $\begin{array}{l}\text { To analyse the influence of IT capabilities on supply chain } \\
\text { capabilities and organizational agility. }\end{array}$ & $\begin{array}{l}\text { IT infrastructure and IT assimilation affect information integration and } \\
\text { operational coordination, and these capabilities also positively influence } \\
\text { organizational agility/Not extended to the flexibility gap closing process }\end{array}$ \\
\hline
\end{tabular}


Table 1. Cont

\begin{tabular}{|c|c|c|}
\hline Study & Research Objectives & Key Findings/Limitation \\
\hline $\begin{array}{l}\text { Kemmoe et al. } \\
2014 \text { [42] }\end{array}$ & $\begin{array}{l}\text { To evaluate production systems by measuring excess } \\
\text { demand that can be satisfied with the systems }\end{array}$ & $\begin{array}{l}\text { A model accommodate unexpected peaks in demand in production capacity is } \\
\text { developed/Focusing on factory-specific flexibility so one cannot use them as } \\
\text { a total set for measurement for IT flexibility dimensions }\end{array}$ \\
\hline $\begin{array}{c}\text { Kumar and } \\
\text { Stylianou, } 2014 \text { [4] }\end{array}$ & $\begin{array}{l}\text { To supply an IT flexibility dedicated management process } \\
\text { framework }\end{array}$ & $\begin{array}{c}\text { A framework for identifying flexibility categories, types of flexibility needed, } \\
\text { understanding synergies and trade-offs between different flexibility types is } \\
\text { developed/No empirical research is presented }\end{array}$ \\
\hline Lee, 2012 [43] & $\begin{array}{l}\text { To develop a theoretical model that explains how firms } \\
\text { achieve business agility from their deployment and } \\
\text { utilization of IT. }\end{array}$ & $\begin{array}{l}\text { Theoretical development on IT exploitation and IT exploration is achieved/No } \\
\text { empirical research is presented. }\end{array}$ \\
\hline $\begin{array}{l}\text { Merschmann and } \\
\text { Thonemann, } 2011 \\
\text { [44] }\end{array}$ & $\begin{array}{l}\text { To highlight the relationship between environmental } \\
\text { uncertainty, supply chain flexibility and firm performance }\end{array}$ & $\begin{array}{l}\text { Proved that the firm performance is conditional and dependent on flexibility } \\
\text { levels and configurations/Not extended to the flexibility gap closing process }\end{array}$ \\
\hline $\begin{array}{c}\text { Seebacher and } \\
\text { Winkler, } 2015 \text { [31] }\end{array}$ & $\begin{array}{l}\text { To evaluate supply chain flexibility by capturing } \\
\text { the performance and efficiency of batch production } \\
\text { systems. }\end{array}$ & $\begin{array}{l}\text { A supply chain's flexibility that satisfies its delivery dates and its operational costs } \\
\text { in the case of changing environment is identified/The application of the model is } \\
\text { restricted to manufacturing process }\end{array}$ \\
\hline
\end{tabular}




\section{Methodology}

\subsection{A Combined IPA and PLS-SEM Method: Background}

This study proposes the combined use of an IPA matrix and PLS-SEM to identify the flexibility gap. While the IPA matrix concept has its origins in marketing [45], it has since been applied in a number of different industry management settings [46-50]. IPA allows a company to detect which attributes of its product or service ought to be improved. Its main structure is a four-dimensional grid based on the importance and performance level of the identified attributes. For instance, for a particular product attribute, importance ratings could be obtained, from "extremely important" to "not important," and, similarly, performance ratings could be obtained, from "excellent" to "poor." Attributes can then be classified according to their relative importance and performance ratings by mapping the scores in a four-dimensional plot. Its introduction to operations management was through Slack [49], who modified the classic $2 \times 2$ importance-performance grid into alternative zones allowing a more constant evolution in inferred priorities. The matrix was later extended by Tontini and Silveira [50]. By incorporating the Kano Model for the arrangement of service features, namely basic, performance and excitement attributes, they developed a way to identify gaps between expected satisfaction, current and average market satisfaction.

A notable aspect of Slack's research [49] is that, based on focus group discussions with company personnel, he configured a zoning representation, as shown in Figure 1. In this representation, companies must determine how well the performance aligns with the line $A B$, which represents the "best fit" with respect to the performance level. Anything below the line requires improvement-or, in extreme cases, as defined by curve $C D$, urgent action. Anything above the line may be deemed appropriate or, if above the curve EF, questionably excessive. As indicated by Slack [49], the AB line does not provide a clear cutoff point where being over (or under) the line definitely indicates being over- (or under-) resourced. Nonetheless, it helps to reveal the potential gap and signals that organisations may need to investigate that are the potential causes of the performance gap.

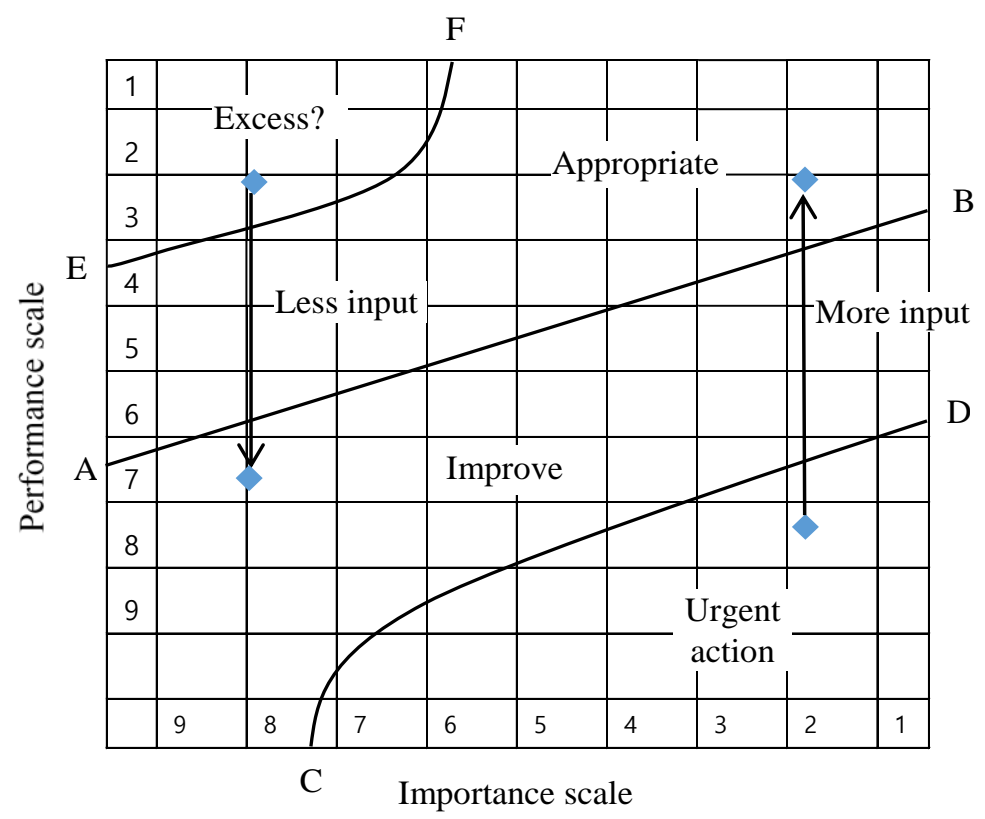

Figure 1. Zoning representation of the IPA matrix (Source: Adapted from Slack 1994).

Recent developments of the IPA matrix have combined the analysis with PLS-SEM applications by Hair et at al. [46] and Ringle and Sarstedt [51]. The process of identifying the flexibility performance gap is elaborated as follows. On the one hand, the importance level on the x-axis of a given matrix denotes the valuation of the direct, indirect and overall relationships between latent constructs. This is 
computed with the inner and outer coefficients. The coefficients range from 0 to 1.0. On the other hand, the performance level is rescaled to 0 to 100 on the y-axis of a given matrix, according to the average scores of the latent construct values. In addition, the scores for the importance level and performance level of each variables are united in a matrix with a bootstrapping method that is employed to measure the significance level of the indicators' importance scores.

\subsection{Application of the Method to IT Flexibility Dimensions}

In this analysis, one can interpret the importance level as the required flexibility level and the performance as the actual flexibility level. Ideally, the most important dimension will show the highest performance score. If the actual performance does not meet the required level, the IPA matrix identifies the performance gap (i.e., the mismatch). Moreover, with this tool we can expand our analysis to the indicator level, thus identifying specific areas that may contribute to the under- or overperforming flexibility dimensions, which may then require rectifying actions [46,51,52].

This method resolves the aforementioned issues in flexibility measurement. First, by providing a universal, all-encompassing measurement, namely performance, different dimensions can be measured in a consistent manner. Second, by providing the two types of measurement, i.e., the importance and performance, this method measures the required and actual flexibility levels simultaneously. Further, as PLS-SEM structural model analysis can demonstrate the impact of independent variables (flexibility dimensions in this case) on dependent variables (firm performance in this case) $[53,54]$, it validates the correlations between flexibility dimensions and firm performance concurrently while testing the uniformity of the dimensions towards firm performance.

Applying IPA with PLS-SEM in our research, we undertook the following steps. First, the results of the IT flexibility model analysis with PLS-SEM with industry-level data are incorporated into an IPA matrix. This step is meant to validate our method in a generalized industry setting, and also to determine whether the general performance levels are consistent with the line $A B$ in Figure 1. If the performance level of each dimension is appropriate when compared to its importance level, that is, consistent with $\mathrm{AB}$, then this tends to indicate that the resources are fairly distributed, and no resource reallocation is required. Second, a case firm that needed IT flexibility improvement was selected, and its data were analysed with the same method to determine if the performance levels are consistent with the line $\mathrm{AB}$ in Figure 1. We also compared the importance and performance levels of the case firm to the general industry results. If the performance levels show different distribution patterns compared to the industry norm, with performance gaps, this strongly indicates that there may be under- or over-resourcing from the case firm. Third, where the case firm's data are not consistent with the line $\mathrm{AB}$, a further analysis was conducted to identify which indicators may require more or fewer resources.

To apply IPA combined with the PLS-SEM method in closing IT flexibility gaps, a model that meets IT flexibility-specific requirements needs to be employed. We applied our method to an existing IT flexibility model proposed by Han et al. [11]. By incorporating exploitive purposes of IT use and an explorative view [55,56], Han et al. [11] classified multiple dimensions of IT flexibility such as transactional IT flexibility, operational IT flexibility and strategic IT flexibility. Transactional (TR) IT flexibility refers to a capability to utilise advances in IT infrastructure. Operational (OP) flexibility is the ability to use IT for information distribution and process enhancement. Strategic (STR) flexibility is the ability to use IT expertise to generate novel, future-oriented operations together with supply chain partners [11]. Such a classification enables us to measure the gap in IT flexibility given that each dimension has different roles. We required a prevalidated model that shows the uniformity of each firm's IT flexibility performance. Based on the theory that IT interacts with intermediate business practices [57], Han et al. [11] showed that IT flexibility is created when the integration of supply chain operations inside the firm and with external business partners is ensured. Thus, Han et al.'s model is well placed to assess the firm performance. One can refer to Han et al. [11] for detailed model development discussions and the hypothesis of the IT flexibility research model. Measurement 
indicators of the three different dimensions of IT flexibility and the hypotheses are presented in Appendix A.

\subsection{Data Collection}

Due to the different IT flexibility dimensions at different organizational levels, the current research requires every respondent to acquire adequate interfirm and functional understanding and experiences at all areas and levels. Our rationale is that senior executives would have a more integrative and strategical perspective, but they might not automatically possess in-depth understanding or experience regarding present working systems. On the other hand, more junior member of staff may be well acquainted with certain IT systems, due to their close engagement with the systems, but may lack a holistic view. Further, the respondents should be capable of assessing the promoting roles of IT flexibility for intra-/interfirm process improvement and the enhancement of firm performance. Respondent validation ensures that the acquired data are reliable and credible for our empirical analysis. Such complex qualifications inevitably reduce the availability of suitable respondents. Because of the aforementioned constraint, this study opted for nonprobability sampling.

Specifically, a mixture of purposive data collection and convenience data collection method was chosen for the current research. The purposive data collection method was selected because it employs the experiences and skills of the researcher to gain well-informed respondents [58,59]. With this data collection method, researchers stipulate the features of a population of interest and attempt to find people who have those features. In the convenience data collection method, the informants are asked to contact new informants, as a focal contact point, who satisfy specific requirements and are willing to take part in specific research [58]. Our survey was organized into five parts (1-5). In order to confirm that the informants satisfy the inclusion principles and measure their ability to assess the dimensions of IT flexibility, a supplementary check was conducted within part 1. It also inquired about the technologies that the informants' firms use to check if the informants are familiar with different IT use patterns, based on the recommendation of Kumar et al. [60]. Further, only the responses from respondents successfully answering the full questionnaire were used for empirical analysis. This data collection method is in line with prior IT flexibility research. By employing a nonprobability data collection method, Gosain et al. [16] collected dependable information from both senior-level respondents and junior-level employees. This is to integrate the insights from the workers associated in daily operations. Rai et al. [61] used similar data collection method as high-level managers are not responsible for repetitive problem settlement and the principal responsibility of the executives is more tactical in nature than the operations conducted by junior-level workers. Parts 2-4 supply questions measuring the level of different dimensions of IT flexibility and other variables (Appendix A). The questions in Part 5 in our survey questionnaire supply general information on the respondents.

For the industry data, the professional network at the authors' university was accessed, which contains professionals who worked at the university for several years on shared research work and information assimilation projects, as well as graduates likely to be familiar with the current research subject. Furthermore, professionals were encouraged to distribute the survey to their co-workers to invite them to take part in the current study. A firm-level dataset was collected within a case company, hereafter known as MultiLogistics. MultiLogistics is a multinational logistics service provider that provides a diverse range of logistics services, such as warehousing, transportation, custom clearance and freight forwarding. Acting as an intermediary, it provides order fulfilment services for a large number of customers, such as telecommunication manufacturers and fashion retailers. It also works with shipping lines and freight transport companies for supply chain execution. The nature of the business indicates that it transmits a large quantity of information and has exhaustive information interchange activities with its customers and business partners. Therefore, IT is critical to the successful execution of MultiLogistics' operations. Under intensifying marketing pressures, whereby logistics services are increasingly seen as a commodity, senior executives feel IT flexibility is an important enabler to allow the company to respond and adapt to a changing environment 
quickly and to remain competitive. Therefore, they feel the need to assess their current IT flexibility and compare it with industry practices to see whether the company is underperforming in certain areas, and to identify opportunities for improvement. We distributed the survey to 62 key informants from over 20 operating units of MultiLogistics globally. In doing so, an international director of the MultiLogistics was actively involved in the data collection. He distributed the survey questionnaire to potentially suitable respondents. Follow-up emails were sent two weeks and four weeks after the initial questionnaire distribution to encourage the respondents to participate in the survey. We followed up our quantitative analysis with qualitative interviews with key respondents from the case company in order to understand the significance of the results from the quantitative stage.

Regarding the industry data $(n=128)$, the analysis of the questionnaire showed that the questionnaires were answered by professionals from production and manufacturing $(22 \%, n=29)$, warehousing and inventory management service $(28 \%, n=36)$, integrated transport service providers $(30 \%, n=38)$, logistics and transport service brokers like 3PL firms $(16 \%, n=20)$ and others $(4 \%$, $n=5)$. The sample included vice presidents or higher position professionals $(4 \%, n=5)$, directors or vice directors $(16 \%, n=21)$, managers or assistant managers $(42 \%, n=54)$, supervisors $(12 \%, n=15)$, operators and clerks $(24 \%, n=31)$ and others $(2 \%, n=2)$, so the survey obtained information covering different areas and levels of an interorganizational business, namely transactional, operational and strategic operations. A majority of informants were from supply chain-related areas $(13 \%, n=17)$ and the transport and logistics field $(71 \%, n=90)$. The sample also included marketing position informants $(8 \%, n=10)$, IT personnel $(2 \%, n=3)$, CEOs $(2 \%, n=3)$ and others $(4 \%, n=5)$. The company's age and number of staff were also captured. To preserve the case firm's anonymity, we will not disclose detailed background information on MultiLogistics. We were able to attain 35 returns. Our sample size seems to be relatively small. However, this study falls into the category of exploratory research. So, a $10 \%$ significance level was thought to be theoretically adequate [46,62]. With a minimum $R^{2}$ of $0.25-0.50$, the required sample size was 34-53 [46] (p. 38). Bearing in mind that the $R^{2}$ from the client firm's model analysis was $0.261-0.735$, the acquired sample size of 35 satisfies the recommended criteria.

\section{Data Analysis}

We investigated the industry-level data by employing PLS-SEM, and then extended the investigation to an IPA matrix method by using SmartPLS 3.0. The scores we calculated serve as the foundation for our investigation.

\subsection{Industry-Level Analysis}

In Table 2, each score of importance and performance level of the different IT flexibility dimensions using the industry data is provided. This is produced using the method described in Section 3. TR IT flexibility showed the highest importance score (0.369). OP IT flexibility had the second-highest score (0.201). STR IT flexibility had the lowest score (0.186) in importance among the three flexibility dimensions. Such an output strongly indicates that TR flexibility's score in performance (i.e., desired performance) should be the highest among the three dimensions. In fact, TR flexibility's actual score in performance was 26.276 . This was the highest score, while OP IT flexibility's performance score is the second highest (23.835). STR flexibility's performance came in third (20.459). The output of the structural model analysis is summarised in Appendix C. In this analysis, the direct influence of STR flexibility on firm performance and indirect influence of TR and OP flexibility on firm performance via PIC is captured. Therefore, correlations between IT flexibility dimensions and firm performance are demonstrated. A validity test for the measurement models is as reported in Han et al. [11]. 
Table 2. Importance-performance level analysis of industry: construct scores.

\begin{tabular}{ccc}
\hline Constructs (Dimensions) & Importance & Performances \\
\hline TR IT flexibility & 0.369 & 26.276 \\
OP IT flexibility & 0.201 & 23.835 \\
STR IT flexibility & 0.186 & 20.459 \\
\hline
\end{tabular}

Source: authors.

From Table 2, we observe that the actual performance levels of different IT flexibility dimension are suitable to their relative levels of importance. Specifically, at the industry level, the resource distribution for the three different IT flexibility dimensions follows a line of "best fit," as given in Figure 1. This is also demonstrated by presenting a trend line among the three different flexibility levels that establish the AB line in Figure 2.

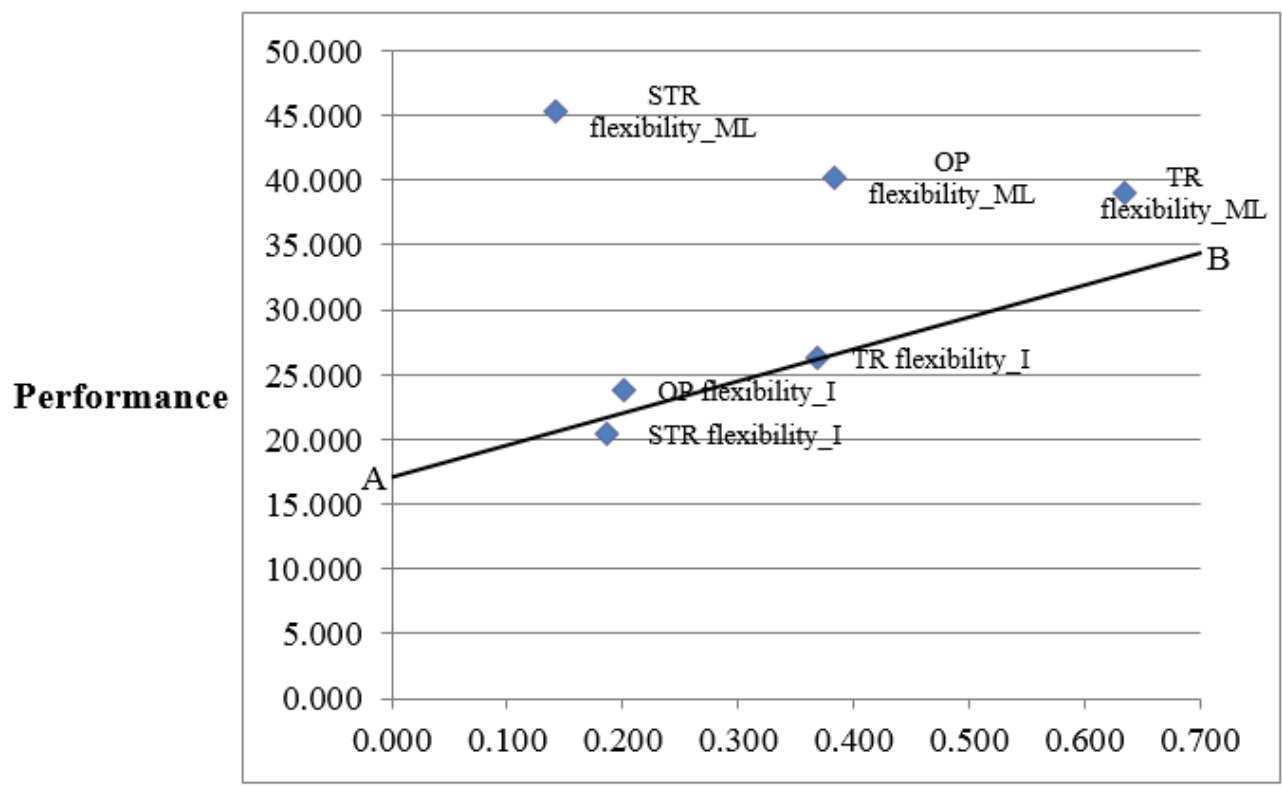

\section{Importance}

Figure 2. Importance-performance analysis of MultiLogistics: construct matrix. Source: authors. (Note: flexibility_I stands for industry and flexibility_ML is for MultiLogistics.)

\subsection{Firm-Level Analysis}

Table 3 shows that MultiLogistics' importance scores are in line with the findings from the industry-level data investigation. However, its performance scores in the three dimensions are inconsistent with the industry results. Notably, TR flexibility's performance score (i.e., desired performance) should be the highest among the three dimensions, as this dimension has been deemed the most important among the three. However, in the case of MultiLogistics, TR IT flexibility showed an actual performance score of 39.013 (the lowest score). In terms of OP flexibility's importance, it had the second-highest score (40.184). With regard to the STR IT flexibility's performance, it came in first (45.363). This indicates that MultiLogistics performed best at the STR dimension, followed by OP, then TR. The detailed PLS-SEM analysis results for MultiLogistics are provided in Appendix D. 
Table 3. Importance-performance analysis of MultiLogistics: Construct scores.

\begin{tabular}{ccc}
\hline Construct (Dimension) & Importance & Performance \\
\hline TR IT flexibility & 0.635 & 39.013 \\
OP IT flexibility & 0.384 & 40.184 \\
STR IT flexibility & 0.142 & 45.363 \\
\hline
\end{tabular}

Source: authors.

Both the industry and MultiLogistics scores were united in a plot, given in Figure 2. As can be identified from Figure 2, MultiLogistics' perception of the order of importance of the three IT flexibility dimensions conforms with the industry-level analysis. However, its performance for the three dimensions is greater than the general industry measure. In particular, MultiLogistics' STR flexibility performance far exceeds the industry norm. This indicates that MultiLogistics may have invested excessively and hence overperformed in this dimension. If the company invested unnecessarily in resources in an effort to build STR flexibility, it might not get the rewards it expected. Alternatively, resources could have been better allocated to other areas, which would have a bigger influence on firm performance. What exactly could have contributed to this potential overperformance? The next section offers further insights via an indicator-level analysis.

\subsection{Indicator-Level Analysis-Development of a Resource Allocation Action Plan}

To identify which indicators of STR flexibility may be consuming resources that could be reallocated to other indicators, the performance of indicators is analysed. Table 4 provides the performance scores of each indicator for both MultiLogistics and the industry as a whole, as well as the score difference between MultiLogistics and the industry. We examine the three STR indicators in particular.

Table 4. The relative performance analysis for MultiLogistics versus the industry: indicator scores.

\begin{tabular}{ccccc}
\hline \multirow{2}{*}{ Dimensions } & \multirow{2}{*}{ Indicator } & \multicolumn{3}{c}{ Performance Score } \\
\cline { 3 - 5 } & & MultiLogistics & Industry & Difference \\
\cline { 3 - 4 } & HW & 40.952 & 23.177 & 17.775 \\
TR & SW & 37.619 & 21.654 & 15.966 \\
flexibility & NW & 28.095 & 19.271 & 8.824 \\
& ACC & 34.706 & 29.134 & 5.572 \\
& LINK & 45.455 & 28.042 & 17.412 \\
& INTP & 42.857 & 38.320 & 4.537 \\
OP & QLT & 37.255 & 20.604 & 16.651 \\
flexibility & VIS & 39.524 & 24.147 & 15.377 \\
& SPD & 40.476 & 22.572 & 17.904 \\
& STMR & 46.667 & 24.800 & 21.867 \\
STR & OPT & 36.667 & 26.640 & 10.026 \\
flexibility & PTN1 & 40.000 & $\mathbf{8 . 8 8 9}$ & $\mathbf{3 1 . 1 1 1}$ \\
& PTN2 & $\mathbf{4 8 . 0 9 5}$ & $\mathbf{3 0 . 5 7 7}$ & $\mathbf{1 7 . 5 1 8}$ \\
& OFF & $\mathbf{4 7 . 0 5 9}$ & $\mathbf{2 3 . 2 2 8}$ & $\mathbf{2 3 . 8 3 0}$ \\
\hline
\end{tabular}

Source: authors.

All three indicators of STR show high performance scores, as expected. However, if one examines the score difference between MultiLogistics and the industry as a whole, there is evidence that some indicators have consumed extensive resources. First, the actual performance of PTN 1 (the ability of the company to establish and adjust information connections with existing supply chain partners) is considerably higher than the industry norm with a gap of 31.111-the largest gap among all 14 flexibility indicators. Moreover, the observed performance of OFF (the ability of the company to use ICT in offering novel products and services to their customers) (47.059) also shows a relatively high score difference (23.830) when compared to the industry score (23.228). The performance of PTN2 (the 
ability of the company to establish and adjust information linkages with new supply chain partners) is of less concern as it is more in line with the other indicators from the TR and OP dimensions.

Such potential overcommitment on PTN1 and OFF could be appropriate due to MultiLogistics' mission to be a truly customer-centric company. Given the increasing market pressure, and the fact that logistics and freight forwarding services are increasingly being perceived as commodities, the company has seen its profit margin being squeezed to a single digit in some regions. Therefore, the company has invested heavily in IT, including implementing a popular commercial transportation management system (TMS) globally, and an enterprise resource planning (ERP) customer relationship management suite to manage its air and freight transactions. According to its annual report, it expected that the flexibility brought about by such investments would provide better visibility to existing and new customers, simplify and speed up information flows, and streamline financial transactions across all its divisions. A lack of information on how the rest of the industry has performed could have led to a potential overcommitment. However, the seeming overinvestment could also be a deliberate act from the company in order to outperform its competitors and retain its leading position in the marketplace.

In order to find the underlying reasons why there is a large gap in PTN1 and OFF between the case company and the industry norm, we conducted a follow-up study. Interviews were conducted with four senior staff from the company: global innovation manager, IT manager, country fulfilment manager and a senior supply chain executive from one of the company's biggest clients, which, in order to retain anonymity, we call TelCo. With each interviewee, we first talked through the rationale of our study and the data analysis results. We then pointed out the gap we identified in the strategic dimension and asked our interviewees what might have contributed to the gap.

The interviews with participants from the case company largely confirmed our initial speculation that the "customer-centric" strategy drives the company's investment decisions in strategic IT flexibility. Investments have been made to streamline internal information integration (e.g., investment on Transport Management Systems and Enterprise Resource Planning) for efficiency and productivity gains. "This is the area that we can control," commented the IT manager. Areas that the case company has less control over but nonetheless must be committed to are building interorganisational information links and improving communications with various clients, particularly with large clients. The biggest challenge is that those large clients tend to have different in-house information systems, and the case company often has to build a dedicated information link with each of the clients, rather than a standard and cost-effective interface with all. The bespoke information connectivity demands a heavy resource commitment and contributes largely to the gap identified in factor PTN1.

The interviewee from TelCo explained why bespoke connectivity is needed in order for them to work with MultiLogistics: “We are a large global manufacturing company and have multiple factories in Europe. MultiLogistics is in charge of our UK order fulfilment process. This means the company needs to be able to interact with a number of our in-house systems. For inbound logistics, they also need to interact with each factory's ERP system to manage and receive goods coming into the UK. We have a central inventory management system that they need to access in order to gain visibility to stock levels. This means their WIS [warehouse information system] needs to integrate with our WIS. For outbound logistics, every time we issue them our customer's PO [purchasing order] and a packing list. They will then have to pick and configure the parts needed for that $\mathrm{PO}$ and send us a picking list via EDI [Electronic Data Interchange] link to our CRM [Customer Relationship Management] system."

As to the gap identified in OFF, the global innovation manager from the case company explained that, different from other logistics companies that tend to outsource many of their IT functions, MultiLogistics manages most of its IT in-house and sees technology as the core of its ability to adapt to changing demands in industry. Unlike asset-heavy logistics companies like DHL, the company's core competitiveness lies in its dynamic capability to continuously innovate and provide value-adding services to their clients. "So rather [than] just managing stocks for our clients, we actually work with our clients to reduce their overall inventories. We'll get paid less [for] warehousing, but we could then implement [a] VMI [vendor-managed inventory] type of exercise and take over our client's 
replenishment function," commented the innovation manager. Other interviewees also commented that a number of explorative initiatives took place in MultiLogistics-for example, introducing manufacturing services and 3D printing. Hence it seems that "overcommitment" under the factor of OFF is a deliberate act that the company undertook to differentiate itself from its competitors. They did acknowledge that they had limited knowledge about how the rest of industry performed, and therefore our tool helped them to gain a clear sense of their competitive position in the marketplace.

By translating the PLS-SEM analysis output to the IPA matrix, the current research has assessed the performance gap in different IT flexibility dimensions. The assessment was based on their relative levels of importance to firm performance. In the case of MultiLogistics, our analysis shows that STR flexibility may overperform, given that its importance does not deviate much from the industry standard. A further indicator-level analysis offers additional insight as to which factors contribute to the possible excessive performance of STR flexibility and where downscaling might be possible. Our follow-up study reveals the complex coercive and competitive forces that drove the case company's deliberate action to commit considerable resources.

\section{Conclusions}

\subsection{Theoretical Contribution}

Previous research has stressed the importance of effective IT flexibility management through a requirements analysis that mitigates deficiencies or excesses in dissimilar flexibility dimensions. Yet there has been a lack of analytical tools that evaluate the required and actual level of IT flexibility dimensions. To resolve this issue, we propose a combined method of IPA and PLS-SEM. Our method shows that prioritization among multiple dimensions of IT flexibility is made by employing the two universal measurements, namely importance and performance. Furthermore, the distribution of firm resources to the most important dimensions is advised.

Application of this method to a client company's data (Multilogistics in this study) also visualizes how this client firm can distribute its resources through the prioritization of different IT flexibility dimensions. In doing so, we proposed an action plan to distribute finite resources to different IT flexibility dimensions in a well-organized and efficient method. The method of PLS-SEM combined with the IPA matrix revealed the most important variables that contribute to the highest level of performance. To the best of the authors' knowledge, there has been no study that has proposed such an analytical tool that assesses multiple dimensions of IT flexibility. The unique contribution of this study is, therefore, an improved understanding of how to get the greatest value out of an investment in IT resources by revealing areas where particular management attention and subsequent rectification may be necessary. By proposing a combined method of IPA and PLS-SEM, we provide a novel insight about the mechanisms that firms can utilize to control their IT flexibility levels in rapidly changing business environments.

The IPA-PLS-SEM tool, however, does not offer detailed explanations as to why companies overcommit in certain areas. There may well be positive and legitimate reasons why companies acted in this way-for example, to maintain a competitive advantage by managing clients who require a certain IT flexibility, as illustrated in the case of MultiLogistics. Or equally, the areas identified could be "blind spots," or mismatches between required and committed investment, that senior executives were not aware of. Those areas could then be targeted for further improvement, or resources could be redeployed elsewhere to deliver improved value to the businesses. Furthermore, without this tool it is not possible to detect the IT flexibility gaps at an indicator level. Consequently, it will be difficult for organisations to develop a strategy for better resource exploitation. Once organisations are confident that the flexibility gaps identified via the use of the IPA-PLS-SEM tool are due to misinvestment in certain areas, action can be undertaken to rectify the situation. Certain resources could be transferred from one area to another in order to achieve the desired IT flexibility outcomes. The concept of resource 
mobility is well established in the literature, and reallocating resources from one dimension to another often incurs lower penalties when compared with additional investment.

\subsection{Practical Contribution}

Our research also suggests a measurement tool that managers can utilize to assess IT flexibility and identify any gaps that exist between current and desired flexibility levels. This output encourages logistics managers to consider the importance of IT flexibility in a more integrative and clear manner. It also helps logistics managers to decide how to coordinate their IT flexibility dimensions efficiently to deal with upcoming changes with finite firm resources. The current literature on quantifiable flexibility measurements has been accused of not being relevant to real-life industry settings. However, in this study, we propose that the IPA tool can be applied directly to industrial practice. Both supply chain and IT managers can use the IPA tool to understand what their competitive priorities should be when examining the performance of their IT flexibility, and identify whether some dimensions may be overor underperforming. This will enable managers to review their IT flexibility capabilities and make more informed choices about where to best concentrate their resources, ultimately increasing managers' abilities to control and manipulate organizational factors to increase firm performance.

\subsection{Limitations and Future Research}

Even though the we did our best to gain many samples for applying the IPA and PLS-SEM combined method to the client firm, the application was performed with a comparatively small sample size $(n=35)$. This is because we required respondents to be key informants who are skilled and well-informed about inclusive IT use, interorganizational process connections and firm performance attributes. Moreover, acquiring 100 individuals from a single firm was a difficult task as the sample pool in a specific company is narrower than in an overall industry sector. If we acknowledge the exploratory characteristics of this study, the sample size is statistically acceptable [46]. However, even though our sample size satisfies the recommended criteria, future research should seek to collect more data to enhance the validity of both industry- and firm-level data.

Although IPA is particularly useful for indicating areas that may either under- or overperform, it does not offer an explanation as to why this happens. As the development of IT flexibility is specific to the operational context, environmental (e.g., industrial advances and market circumstances), organisational (e.g., firm scale, tactics and monetary condition) and technological (e.g., IT proficiency and human resources, architecture and IT merchants) issues can affect the required IT flexibility level. Further investigation is thus needed to understand whether a company is indeed over- or underperforming in a specific dimension. As the IPA matrix assumes linear relationships between importance and performance, this study does not address lines CD and EF (shown in Figure 1). Considerations of possible nonlinear relationships, such as the one proposed by Tontini and Silveira [50], could complement our approach. Future research could also attempt to apply this tool to other, non-IT types of flexibility.

Author Contributions: Conceptualization, J.H.H.; methodology, J.H.H.; Y.W. and M.N.; formal analysis, J.H.H. and Y.W.; writing - original draft preparation, J.H.H. and Y.W.; writing-review and editing, Y.W. and M.N.; visualization, J.H.H.; supervision, Y.W. and M.N.; project administration, Y.W. All authors have read and agreed to the published version of the manuscript.

Funding: This research received no external funding.

Conflicts of Interest: The authors declare no conflict of interest. 


\section{Appendix A}

Table A1. Multiple dimensions of IT flexibility.

\begin{tabular}{|c|c|c|c|}
\hline Dimensions & Subdimensions & $\begin{array}{c}\text { Indicators } \\
\text { (Abbreviations) }\end{array}$ & Explanations \\
\hline \multirow{6}{*}{$\begin{array}{l}\text { Transactional } \\
\text { Flexibility }\end{array}$} & \multirow{3}{*}{ IT Infrastructure } & Hardware (HW) & $\begin{array}{c}\text { We can successfully transact with external firms } \\
\text { by using our advanced hardware (e.g., } \\
\text { computers, field devices, sensors, meters, } \\
\text { servers, etc.) }\end{array}$ \\
\hline & & Software (SW) & $\begin{array}{c}\text { We can successfully transact with external firms } \\
\text { by using our advanced software and } \\
\text { applications (e.g., logistics portals, email } \\
\text { systems, etc.) }\end{array}$ \\
\hline & & Networks (NW) & $\begin{array}{l}\text { We can successfully transact with external firms } \\
\text { by using our advanced network (e.g., internet, } \\
\text { LAN, telephone, text) }\end{array}$ \\
\hline & \multirow{3}{*}{ Connectivity } & Access (ACC) & $\begin{array}{c}\text { We can effectively access our IT network } \\
\text { properly and securely to communicate with } \\
\text { external firms (e.g., network access anytime } \\
\text { anywhere) }\end{array}$ \\
\hline & & Linkages (LINK) & $\begin{array}{l}\text { We can access a wide range of external firms } \\
\text { through our IT network (e.g., number of } \\
\text { external firms we can access through our portal }\end{array}$ \\
\hline & & $\begin{array}{l}\text { Interoperability } \\
\quad \text { (INTP) }\end{array}$ & $\begin{array}{l}\text { We can effectively transact with our external } \\
\text { firms through standardized information format } \\
\text { (e.g., Excel, PDF, HTML, EDI) }\end{array}$ \\
\hline \multirow{5}{*}{$\begin{array}{l}\text { Operational } \\
\text { Flexibility }\end{array}$} & \multirow{3}{*}{ Information sharing } & Quality (QLT) & We can share accurate and timely information \\
\hline & & Visibility (VIS) & $\begin{array}{l}\text { We can gain good visibility of supply chain } \\
\text { processes }\end{array}$ \\
\hline & & Speed (SPD) & We can complete transactions rapidly \\
\hline & \multirow{2}{*}{ Process improvement } & $\begin{array}{l}\text { Streamlining } \\
\text { (STMR) }\end{array}$ & $\begin{array}{l}\text { We can integrate and automate supply chain } \\
\text { processes }\end{array}$ \\
\hline & & $\begin{array}{l}\text { Optimisation } \\
\text { (OPT) }\end{array}$ & $\begin{array}{l}\text { We can optimise the supply chain processes } \\
\text { with external firm }\end{array}$ \\
\hline \multirow{3}{*}{$\begin{array}{l}\text { Strategic } \\
\text { Flexibility }\end{array}$} & \multirow{2}{*}{ Partnering } & $\begin{array}{l}\text { Partnering1 } \\
\text { (PTN1) }\end{array}$ & $\begin{array}{c}\text { We can easily build and alter our information } \\
\text { linkages to our existing supply chain partners } \\
\text { providers }\end{array}$ \\
\hline & & $\begin{array}{l}\text { Partnering } 2 \\
\text { (PTN2) }\end{array}$ & $\begin{array}{l}\text { We can easily build and alter our information } \\
\text { linkages to new supply chain partners }\end{array}$ \\
\hline & Offering & Offering (OFF) & $\begin{array}{l}\text { We are actively exploring innovative ways of } \\
\text { using ICT in offering new products or services } \\
\text { to customers }\end{array}$ \\
\hline \multirow{3}{*}{ Process integ } & \multirow{3}{*}{ ation capability (PIC) } & PIC 1 & $\begin{array}{l}\text { We have a capability to integrate sourcing, } \\
\text { transport, service process and other areas } \\
\text { internally }\end{array}$ \\
\hline & & PIC 2 & $\begin{array}{l}\text { We have a capability to integrate sourcing, } \\
\text { transport, service process and other areas with } \\
\text { suppliers }\end{array}$ \\
\hline & & PIC 3 & $\begin{array}{l}\text { We have a capability to integrate sourcing, } \\
\text { transport, service process and other areas with } \\
\text { customers }\end{array}$ \\
\hline
\end{tabular}


Table A1. Cont.

\begin{tabular}{|c|c|c|}
\hline Subdimensions & $\begin{array}{c}\text { Indicators } \\
\text { (Abbreviations) }\end{array}$ & Explanations \\
\hline \multirow{5}{*}{ Firm performance (FP) } & Cost (COST) & $\begin{array}{l}\text { Transaction costs for your supply chain } \\
\text { operations is reduced }\end{array}$ \\
\hline & Service (SRV) & $\begin{array}{l}\text { Level of service provided to customer is } \\
\text { improved }\end{array}$ \\
\hline & Speed (SPD_P) & Speed of supply chain operations is improved \\
\hline & Quality (QLT_P) & Quality of service to customers is improved \\
\hline & Value (Value) & Value creation in the supply chain is improved \\
\hline
\end{tabular}

Source: adapted from Han et al. [11].

\section{Appendix B}

Table A2. Hypotheses for IT flexibility research model.

\begin{tabular}{|c|c|}
\hline Types & Hypotheses \\
\hline Hierarchical structure of IT flexibility & $\begin{array}{l}\text { Transactional IT flexibility positively affects } \\
\text { Operational IT flexibility. } \\
\text { Transactional IT flexibility positively affects Strategic } \\
\text { IT flexibility. } \\
\text { Operational IT flexibility positively affects Strategic IT } \\
\text { flexibility. }\end{array}$ \\
\hline $\begin{array}{l}\text { Indirect impact of IT flexibility dimensions on firm } \\
\text { performance }\end{array}$ & $\begin{array}{c}\text { Transactional IT flexibility positively affects Process } \\
\text { Integration Capability. } \\
\text { Operational IT flexibility positively affects Process } \\
\text { Integration Capability. } \\
\text { Strategic IT flexibility positively affects Process } \\
\text { Integration Capability. }\end{array}$ \\
\hline $\begin{array}{l}\text { Direct impact of IT flexibility dimensions on firm } \\
\text { performance }\end{array}$ & $\begin{array}{c}\text { Transactional IT flexibility positively affects firm } \\
\text { performance. } \\
\text { Operational IT flexibility positively affects firm } \\
\text { performance. } \\
\text { Strategic IT flexibility positively affects firm } \\
\text { performance. }\end{array}$ \\
\hline Impact of mediator on firm performance & $\begin{array}{c}\text { Process Integration Capability positively affects firm } \\
\text { performance. }\end{array}$ \\
\hline
\end{tabular}




\section{Appendix C}

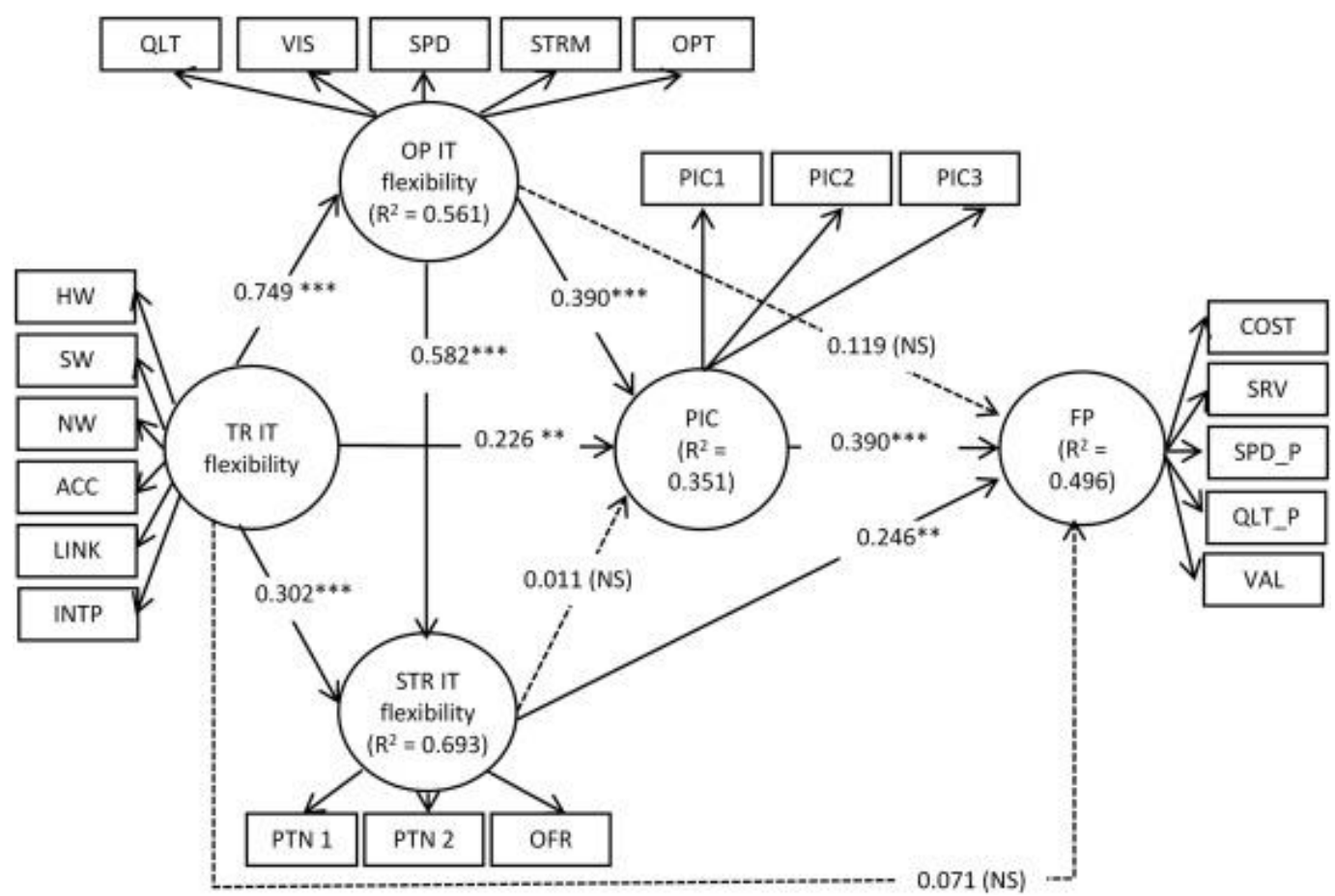

Figure A1. PLS-SEM test results for industry-level data (** $p<0.05,{ }^{* * *} p<0.01$, NS: Non-Significant).

\section{Appendix D}

Table A3. PLS-SEM test results for MultiLogistics. Summary of validity test results of the measurement model.

\begin{tabular}{cccccc}
\hline \multirow{2}{*}{ Latent Variables } & $\begin{array}{c}\text { Number of } \\
\text { Indicators }\end{array}$ & \multicolumn{2}{c}{$\begin{array}{c}\text { Internal Consistency } \\
\text { Reliability }\end{array}$} & $\begin{array}{c}\text { Convergent } \\
\text { Validity }\end{array}$ & $\begin{array}{c}\text { Indicator } \\
\text { Reliability }\end{array}$ \\
\cline { 3 - 6 } & & $\begin{array}{c}\text { Composite } \\
\text { Reliability }\end{array}$ & $\begin{array}{c}\text { Cronbach's } \\
\text { Alpha }\end{array}$ & AVE & $\begin{array}{c}\text { Factor } \\
\text { Loadings }\end{array}$ \\
\hline TR IT flexibility & 6 & 0.918 & 0.894 & 0.655 & 0.619 to 0.898 \\
OP IT flexibility & 5 & 0.940 & 0.920 & 0.758 & 0.831 to 0.898 \\
STR IT flexibility & 3 & 0.919 & 0.868 & 0.792 & 0.854 to 0.945 \\
Process integration capability & 3 & 0.911 & 0.856 & 0.773 & 0.869 to 0.888 \\
Firm performance & 5 & 0.954 & 0.940 & 0.807 & 0.848 to 0.953 \\
\hline
\end{tabular}

Table A4. PLS-SEM test results for MultiLogistics. Fornell-Larcker criterion.

\begin{tabular}{|c|c|c|c|c|c|}
\hline Latent Variables & $\begin{array}{c}\text { Process } \\
\text { Integration } \\
\text { Capability }\end{array}$ & $\begin{array}{c}\text { Firm } \\
\text { Performance }\end{array}$ & $\begin{array}{c}\text { Operational } \\
\text { Flexibility }\end{array}$ & $\begin{array}{l}\text { Strategic } \\
\text { Flexibility }\end{array}$ & $\begin{array}{c}\text { Transactional } \\
\text { Flexibility }\end{array}$ \\
\hline $\begin{array}{l}\text { Process integration } \\
\text { capability }\end{array}$ & 0.879 & & & & \\
\hline Firm performance & 0.422 & 0.898 & & & \\
\hline $\begin{array}{c}\text { Operational } \\
\text { flexibility }\end{array}$ & 0.498 & 0.757 & 0.871 & & \\
\hline Strategic flexibility & 0.361 & 0.715 & 0.739 & 0.890 & \\
\hline $\begin{array}{c}\text { Transactional } \\
\text { flexibility }\end{array}$ & 0.401 & 0.689 & 0.692 & 0.805 & 0.809 \\
\hline
\end{tabular}


Table A5. PLS-SEM test results for MultiLogistics. Cross-loading analysis.

\begin{tabular}{cccccc}
\hline & $\begin{array}{c}\text { TR } \\
\text { Flexibility }\end{array}$ & $\begin{array}{c}\text { OP } \\
\text { Flexibility }\end{array}$ & $\begin{array}{c}\text { STR } \\
\text { Flexibility }\end{array}$ & $\begin{array}{c}\text { Process Integration } \\
\text { Capability }\end{array}$ & $\begin{array}{c}\text { Firm } \\
\text { Performance }\end{array}$ \\
\hline HW & $\mathbf{0 . 8 9 8}$ & 0.715 & 0.759 & 0.446 & 0.588 \\
SW & $\mathbf{0 . 8 8 9}$ & 0.603 & 0.785 & 0.208 & 0.584 \\
NW & $\mathbf{0 . 8 1 7}$ & 0.331 & 0.544 & 0.168 & 0.349 \\
ACC & $\mathbf{0 . 7 2 4}$ & 0.404 & 0.514 & 0.341 & 0.638 \\
LINK & $\mathbf{0 . 8 7 0}$ & 0.762 & 0.874 & 0.474 & 0.678 \\
INTP & $\mathbf{0 . 6 1 9}$ & 0.312 & 0.287 & 0.173 & 0.397 \\
QLT & 0.550 & $\mathbf{0 . 8 5 4}$ & 0.556 & 0.404 & 0.700 \\
VIS & 0.633 & $\mathbf{0 . 8 9 7}$ & 0.711 & 0.448 & 0.671 \\
SPD & 0.565 & $\mathbf{0 . 8 7 2}$ & 0.677 & 0.543 & 0.732 \\
STMR & 0.678 & $\mathbf{0 . 8 9 8}$ & 0.742 & 0.376 & 0.603 \\
OPT & 0.582 & $\mathbf{0 . 8 3 1}$ & 0.508 & 0.389 & 0.584 \\
PTN1 & 0.588 & 0.710 & $\mathbf{0 . 8 5 1}$ & 0.227 & 0.576 \\
PTN2 & 0.810 & 0.635 & $\mathbf{0 . 9 4 5}$ & 0.337 & 0.661 \\
OFF & 0.783 & 0.640 & $\mathbf{0 . 8 7 1}$ & 0.385 & 0.665 \\
PIC1 & 0.428 & 0.439 & 0.412 & $\mathbf{0 . 8 6 9}$ & 0.430 \\
PIC2 & 0.215 & 0.314 & 0.178 & $\mathbf{0 . 8 8 8}$ & 0.224 \\
PIC3 & 0.363 & 0.509 & 0.309 & $\mathbf{0 . 8 8 0}$ & 0.401 \\
COST & 0.590 & 0.751 & 0.680 & 0.351 & $\mathbf{0 . 8 4 8}$ \\
SVC & 0.694 & 0.663 & 0.637 & 0.399 & $\mathbf{0 . 9 1 3}$ \\
SPD_P & 0.589 & 0.684 & 0.628 & 0.304 & $\mathbf{0 . 9 1 7}$ \\
QLT_P & 0.685 & 0.673 & 0.685 & 0.429 & $\mathbf{0 . 9 5 3}$ \\
VAL & 0.523 & 0.619 & 0.570 & 0.415 & $\mathbf{0 . 8 5 6}$ \\
\hline
\end{tabular}

Table A6. Effects and variance explained.

\begin{tabular}{ccc}
\hline $\begin{array}{c}\text { Effects on Endogenous Variable with } \\
\text { Hypotheses }\end{array}$ & Path Coefficient $\boldsymbol{\beta}(\boldsymbol{t}$-Value) & Variance Explained $\left(\boldsymbol{R}^{\mathbf{2})}\right.$ \\
\hline Effects on OP flexibility & - & 0.478 \\
H1a: TR $\rightarrow$ OP & $0.692^{* * *}(7.718)$ & - \\
Effects on STR flexibility & - & 0.735 \\
H1b: TR $\rightarrow$ STR & $0.600^{* * *}(5.418)$ & - \\
H1c: OP $\rightarrow$ STR & $0.324^{* * *}(3.020)$ & - \\
Effects on PIC & - & -261 \\
H2a: TR $\rightarrow$ PIC & $0.203(0.659, \mathrm{NS})$ & - \\
H2b: OP $\rightarrow$ PIC & $0.474 * *(2.123)$ & - \\
H2c: STR $\rightarrow$ PIC & $-0.157(0.397, N S)$ & 0.639 \\
Effects on FP & - & - \\
H3a: TR $\rightarrow$ FP & $0.179(0.921 \mathrm{NS})$ & - \\
H3b: OP $\rightarrow$ FP & $0.446^{* *}(2.224)$ & - \\
H3c: STR $\rightarrow$ FP & $0.220(0.971, \mathrm{NS})$ & - \\
H4: PIC $\rightarrow$ FP & $0.049(0.320, \mathrm{NS})$ & \\
\hline
\end{tabular}




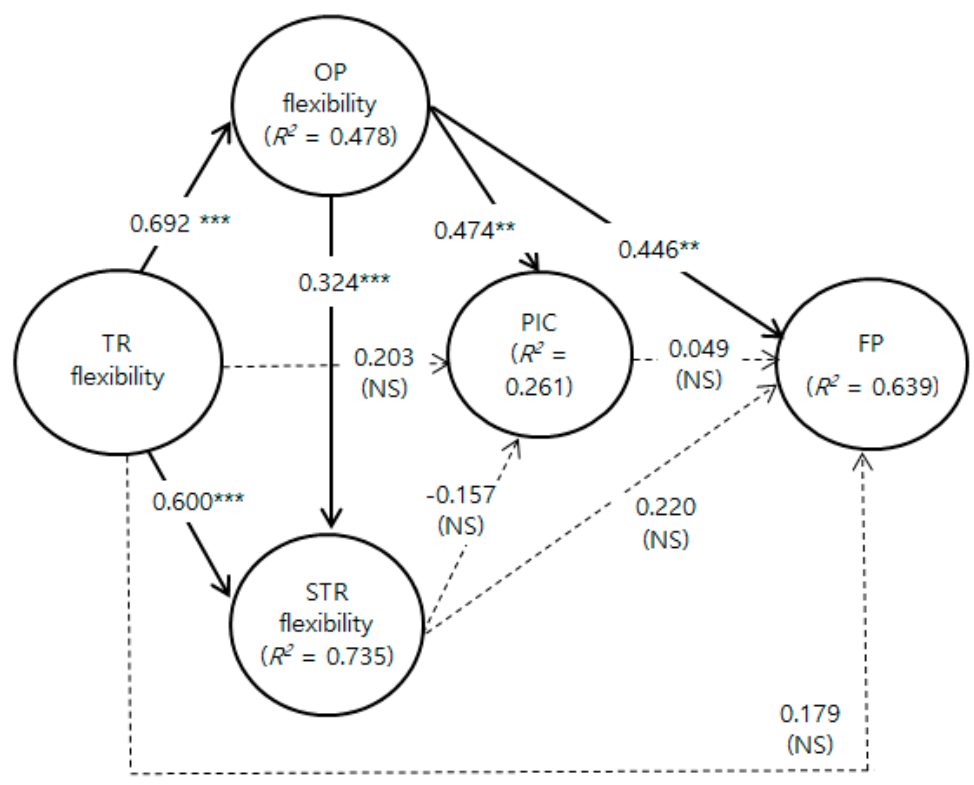

Figure A2. Result of path analysis-Company A. ( ${ }^{* *} p<0.05,{ }^{* * *} p<0.01$, NS: Non-Significant).

\section{References}

1. Duncan, N.B. Capturing Flexibility of Information Technology Infrastructure: A Study of Resource Characteristics and their Measure. J. Manag. Inf. Syst. 1995, 12, 37-57. [CrossRef]

2. Gebauer, J.; Schober, F. Information system flexibility and the cost efficiency of business processes. J. Assoc. Inf. Syst. 2006, 7, 122-147. [CrossRef]

3. Bush, A.; Tiwana, A.; Rai, A. Complementarities between product design modularity and IT infrastructure flexibility in IT-enabled supply chains. Eng. Manag. IEEE Trans. 2010, 57, 240-254. [CrossRef]

4. Kumar, R.L.; Stylianou, A.C. A process model for analyzing and managing flexibility in information systems. Eur. J. Inf. Syst. 2014, 23, 151-184. [CrossRef]

5. Ngai, E.; Chau, D.; Chan, T. Information technology, operational, and management competencies for supply chain agility: Findings from case studies. J. Strateg. Inf. Syst. 2011, 20, 232-249. [CrossRef]

6. Saraf, N.; Langdon, C.S.; Gosain, S. IS Application Capabilities and Relational Value in Interfirm Partnerships. Inf. Syst. Res. 2007, 18, 320-339. [CrossRef]

7. Tafti, A.; Mithas, S.; Krishnan, M.S. The effect of information technology-enabled flexibility on formation and market value of alliances. Manag. Sci. 2013, 59, 207-225. [CrossRef]

8. Tallon, P.P.; Pinsonneault, A. Competing perspectives on the link between strategic information technology alignment and organizational agility: Insights from a mediation model. MIS Q. 2011, 35, 463-484. [CrossRef]

9. Zhang, J.; Li, H.; Ziegelmayer, J.L. Resource or capability? A dissection of SMEs' IT infrastructure flexibility and its relationship with IT responsiveness. J. Comput. Inf. Syst. 2009, 50, 46-53.

10. Nelson, K.M.; Ghods, M. Measuring technology flexibility. Eur. J. Inf. Syst. 1998, 7, 232-240. [CrossRef]

11. Shi, D.; Daniels, R. A survey of manufacturing flexibility: Implications for e-business flexibility. IBM Syst. J. 2003, 42, 414-427. [CrossRef]

12. Byrd, T.A.; Turner, D.E. Measuring the Flexibility of Information Technology Infrastructure: Exploratory Analysis of a Construct. J. Manag. Inf. Syst. 2000, 17, 167-208.

13. Han, J.H.; Wang, Y.; Naim, M. Reconceptualization of information technology flexibility for supply chain management: An empirical study. Int. J. Prod. Econ. 2017, 187, 196-215. [CrossRef]

14. Armstrong, C.; Sambamurthy, V. Information technology assimilation in firms: The influence of senior leadership and IT infrastructures. Inf. Syst. Res. 1999, 10, 304-327. [CrossRef]

15. Bhatt, G.; Emdad, A.; Roberts, N.; Grover, V. Building and leveraging information in dynamic environments: The role of IT infrastructure flexibility as enabler of organizational responsiveness and competitive. Inf. Manag. 2010, 47, 341-349. [CrossRef] 
16. Gosain, S.; Malhotra, A.; El Sawy, O.A. Coordinating for Flexibility in e-Business Supply Chains. J. Manag. Inf. Syst. 2004, 21, 7-45. [CrossRef]

17. Lee, G.; Xia, W. The ability of information systems development project teams to respond to business and technology changes: A study of flexibility measures. Eur. J. Inf. Syst. 2005, 14, 75-92. [CrossRef]

18. Kwak, S.-Y.; Cho, W.-S.; Seok, G.-A.; Yoo, S.-G. Intention to Use Sustainable Green Logistics Platforms. Sustainability 2020, 12, 3502. [CrossRef]

19. Boyle, T.A. Towards best management practices for implementing manufacturing flexibility. J. Manuf. Technol. Manag. 2006, 17, 6-21. [CrossRef]

20. Fayezi, S.; Zutshi, A.; O'Loughlin, A. Developing an analytical framework to assess the uncertainty and flexibility mismatches across the supply chain. Bus. Process Manag. J. 2014, 20, 362-391. [CrossRef]

21. Gerwin, D. Manufacturing Flexibility: A Strategic Perspective. Manag. Sci. 1993, 39, 395-410. [CrossRef]

22. Jordan, W.C.; Graves, S.C. Principles on the Benefits of Manufacturing Process Flexibility. Manag. Sci. 1995, 41, 577-594. [CrossRef]

23. Suarez, F.F.; Cusumano, M.A.; Fine, C.H. Flexibility and Performance: A Literature Critique and Strategic Framework; Sloan School, Massachusetts Institute of Technology: Cambridge, MA, USA, 1991.

24. Kumar, V.; Fantazy, K.A.; Kumar, U.; Boyle, T.A. Implementation and management framework for supply chain flexibility. J. Enterp. Inf. Manag. 2006, 19, 303-319. [CrossRef]

25. He, P.; Xu, X.; Hua, Z. A new method for guiding process flexibility investment: Flexibility fit index. Int. J. Prod. Res. 2012, 50, 3718-3737. [CrossRef]

26. Jain, A.; Jain, P.K.; Chan, F.T.; Singh, S. A review on manufacturing flexibility. Int. J. Prod. Res. 2013, 51, 5946-5970. [CrossRef]

27. Cousens, A.; Szwejczewski, M.; Sweeney, M. A process for managing manufacturing flexibility. Int. J. Oper. Prod. Manag. 2009, 29, 357-385. [CrossRef]

28. Gerwin, D. An Agenda for Research on the Flexibility of Manufacturing Processes. Int. J. Oper. Prod. Manag. 1987, 7, 38-49. [CrossRef]

29. Sethi, A.; Sethi, S. Flexibility in manufacturing: A survey. Int. J. Flex. Manuf. Syst. 1990, 2, $289-328$. [CrossRef]

30. Upton, D. The management of manufacturing flexibility. Calif. Manag. Rev. 1994, 36, 72-89. [CrossRef]

31. Seebacher, G.; Winkler, H. A capability approach to evaluate supply chain flexibility. Int. J. Prod. Econ. 2015, 167, 177-186. [CrossRef]

32. Stevenson, M.; Spring, M. Flexibility from a supply chain perspective: Definition and review. Int. J. Oper. Prod. Manag. 2007, 27, 685-713. [CrossRef]

33. Upton, D. What really makes factories flexible? Harv. Bus. Rev. 1995, 73, 74-84.

34. Chang, A.-Y. Prioritising the types of manufacturing flexibility in an uncertain environment. Int. J. Prod. Res. 2012, 50, 2133-2149. [CrossRef]

35. Lee, O.K. IT-Enabled Organizational Transformations to Achieve Business Agility. Rev. Bus. Inf. Syst. 2012, 16, 43. [CrossRef]

36. Hou, C.K. The effects of IT infrastructure integration and flexibility on supply chain capabilities and organizational performance: An empirical study of the electronics industry in Taiwan. Inf. Dev. 2019, 1-27. [CrossRef]

37. Gao, P.; Zhang, J.; Gong, Y.; Li, H. Effects of technical IT capabilities on organizational agility: The moderating role of IT business spanning capability. Ind. Manag. Data Syst. 2020, 120, 941-961. [CrossRef]

38. Irfan, M.; Wang, M.; Akhtar, N. Impact of IT capabilities on supply chain capabilities and organizational agility: A dynamic capability view. Oper. Manag. Res. 2019, 12, 113-128. [CrossRef]

39. Benitez, J.; Ray, G.; Henseler, J. Impact of Information Technology Infrastructure Flexibility on Mergers and Acquisitions. MIS Q. 2018, 42, 25-43. [CrossRef]

40. Bamel, U.K.; Bamel, N. Organizational resources, KM process capability and strategic flexibility: A dynamic resource-capability perspective. J. Knowl. Manag. 2018, 22, 1555-1572. [CrossRef]

41. Benitez, J.; Llorens, J.; Braojos, J. How information technology influences opportunity exploration and exploitation firm's capabilities. Inf. Manag. 2018, 55, 508-523. [CrossRef]

42. Chaudhuri, A.; Boer, H.; Taran, Y. Supply chain integration, risk management and manufacturing flexibility. Int. J. Oper. Prod. Manag. 2018, 38, 690-712. [CrossRef] 
43. Kemmoe, S.; Pernot, P.-A.; Tchernev, N. Model for flexibility evaluation in manufacturing network strategic planning. Int. J. Prod. Res. 2014, 52, 4396-4411. [CrossRef]

44. Martilla, J.A.; James, J.C. Importance-Performance Analysis. J. Mark. 1977, 41, 77. [CrossRef]

45. Slack, N. The Importance-Performance Matrix as a Determinant of Improvement Priority. Int. J. Oper. Prod. Manag. 1994, 14, 59-75. [CrossRef]

46. Tontini, G.; Silveira, A. Identification of satisfaction attributes using competitive analysis of the improvement gap. Int. J. Oper. Prod. Manag. 2007, 27, 482-500. [CrossRef]

47. Pezeshki, V.; Mousavi, A.; Grant, S. Importance-performance analysis of service attributes and its impact on decision making in the mobile telecommunication industry. Meas. Bus. Excell. 2009, 13, 82-92. [CrossRef]

48. Hair, J.F.; Ringle, C.M.; Sarstedt, M. Partial Least Squares Structural Equation Modeling: Rigorous Applications, Better Results and Higher Acceptance. Long Range Plan. 2013, 46, 1-12. [CrossRef]

49. Lai, I.K.W.; Hitchcock, M. Importance-performance analysis in tourism: A framework for researchers. Tour. Manag. 2015, 48, 242-267. [CrossRef]

50. Rigdon, E.; Ringle, C. Assessing heterogeneity in customer satisfaction studies: Across industry similarities and within industry differences. Adv. Int. Mark. 2011, 22, 169-194.

51. Ringle, C.M.; Sarstedt, M. Gain more insight from your PLS-SEM results. Ind. Manag. Data Syst. 2016, 116, 1865-1886. [CrossRef]

52. Hair, J.F., Jr.; Hult, G.T.M.; Ringle, C.; Sarstedt, M. A Primer on Partial Least Squares Structural Equation Modeling (PLS-SEM), 1st ed.; SAGE Publication Ltd.: Thousand Oaks, CA, USA, 2013.

53. Rigdon, E.E. Choosing PLS path modeling as analytical method in European management research: A realist perspective. Eur. Manag. J. 2016, 34, 598-605. [CrossRef]

54. Hair, J.F.; Hult, G.T.M.; Ringle, C.; Sarstedt, M. A Primer on Partial Least Squares Structural Equation Modeling (PLS-SEM), 2nd ed.; SAGE Publications: Thousand Oaks, CA, USA, 2017.

55. Schmitz, K.W.; Teng, J.T.C.; Webb, K.J. Capturing the Complexity of Malleable IT Use: Adaptive Structuration Theory for Individuals Availability: In stock. MIS Q. 2016, 40, 663-686. [CrossRef]

56. Subramani, M. How do suppliers benefit from information technology use in supply chain relationships? MIS Q. 2004, 28, 45-73. [CrossRef]

57. Melville, N.; Kraemer, K.; Gurbaxani, V. Review: Information technology and organizational performance: An integrative model of IT business value. MIS Q. 2004, 28, 283-322. [CrossRef]

58. Bryman, A.; Bell, E. Business Research Methods; Oxford University Press: New York, NY, USA, 2012.

59. Saunders, M.N.K.; Lewis, P.; Thornhill, A. Research Methods for Business Students, 6th ed.; Pearson Education Limited: Harlow, UK, 2012.

60. Kumar, N.; Stern, L.; Anderson, J. Conducting interorganizational research using key informants. Acad. Manag. J. 1993, 36, 1633-1651.

61. Rai, A.; Pavlou, P.A.; Im, G.; Du, S. Interfirm IT Capability Profiles and Communications for Cocreating Relational Value: Evidence from the Logistics Industry. MIS Q. 2012, 36, 233-262. [CrossRef]

62. Reinartz, W.; Haenlein, M.; Henseler, J. An empirical comparison of the efficacy of covariance-based and variance-based SEM. Int. J. Res. Mark. 2009, 26, 332-344. [CrossRef]

(C) 2020 by the authors. Licensee MDPI, Basel, Switzerland. This article is an open access article distributed under the terms and conditions of the Creative Commons Attribution (CC BY) license (http://creativecommons.org/licenses/by/4.0/). 